\title{
FACTOR ANALYSIS OF FINANCIAL STANDING OF THE SHANGHAI COOPERATION ORGANISATION MEMBER STATES
}
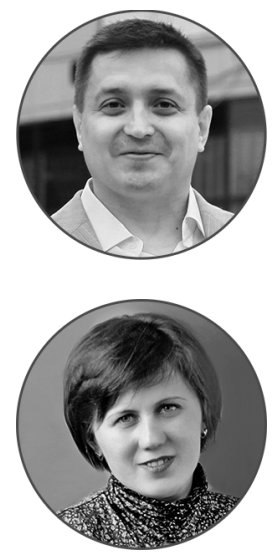

Article history:

Received 13 March 2018

Received in revised form 29 March 2018

Accepted 30 April 2018

Translated 14 December2018

Available online 24 December 2018

JEL classification: C13, C43, E02, E10, F01, F15, F62

Keywords: amplitude, polynomial approximation, growth rate, factor analysis, financial standing

Valerii V. SMIRNOV

I.N. Ulianov Chuvash State University, Cheboksary, Chuvash Republic, Russian Federation

walera712006@mail.ru

https://orcid.org/0000-0002-6198-3157

Corresponding author

\section{Alena V. MULENDEEVA}

I.N. Ulianov Chuvash State University, Cheboksary, Chuvash Republic, Russian Federation alena-mulendeeva@yandex.ru

\begin{abstract}
Subject The article focuses on the financial position of the Shanghai Cooperation Organisation nations.

Objectives This research represents factor analysis of trends in the financial standing of the Shanghai Cooperation Organisation countries and assesses an increment in a set of interdependencies with subsequent polynomial approximation. Methods We draw upon fundamental principles of the factor analysis theory and practice, laws of economic and finance, findings of scholarly studies into the equilibrium and non-equilibrium development of global economy and world order by country.

Results We identify countries demonstrating high and low growth rates of inderdependencies and high and low instability in terms of absolute peak values.

Conclusions and Relevance Analyzing the 2006-2016 period, we capture high growth rates in Tajikistan (liquid bank reserves to assets ratio), Kyrgyzstan (extensive money supply, inflation, consumer prices), Kazakhstan (foreign exchange rate), Uzbekistan (deflator), Russia (loan interest rate for the private sector), China (national trading companies), and high absolute peak values of instability in Kazakhstan (liquid bank reserves to assets ratio), Tajikistan (extensive money supply), India (foreign exchange rate), Russia (deflator, national trading companies), China (inflation, consumer prices), Kyrgyzstan (loan interest rates for the private sector). The findings would be useful in outlining and adjusting the international policy and foreign trade with the Shanghai Cooperation Organisation countries and improving the implementation mechanisms.
\end{abstract}

(c) Publishing house FINANCE and CREDIT, 2018

The editor-in-charge of this article was Irina M. Vechkanova

Authorized translation by Irina M. Vechkanova

\section{Introduction}

Intensifying competition and rearrangements in the global economic leadership necessitate finding

${ }^{\dagger}$ For the source article, please refer to: Смирнов B.B., Мулендеева А.В. Факторный анализ динамики финансовой состоятельности стран Шанхайской организации сотрудничества. Экономический анализ: теория и практика. 2018. Т. 17. № 8. C. 1545-1563. URL: https://doi.org/10.24891/ea.17.8.1545 modern and effective options of international cooperation. An international cooperation organization should continuously and constantly monitor how its capabilities are formed and subsequently exercised as its pursues its interests in the ever changing global environment and fierce competition. Evaluating and subsequently analyzing such capabilities, the international cooperation organization revises 
opportunities it and some of its members have to strengthen their positions in the global economic process and influence the world order.

Factor analysis is quite a popular and frequent technique the Russian researchers resort to in order to evaluate the performance and development of business entities in certain economic systems [1, p.4], analyze the solvency of borrowers [2, p. 4], build econometric models to review the current tendencies and forecast the future scenarios [3, p. 18], impact of sustainable development factors on the effectiveness of the investment decision making process [4, p. 48]. This technique is also deployed to forge a set of indicators and apply them to evaluate capabilities [5, p. 154], create models for a comprehensive technological and economic evaluation of new and conventional technologies [6, p. 154]. Foreign researchers also opt for factor analysis when studying a choice and implications of types of preferential agreements on economic integration [7, p. 143], polarization of neighboring regions where spatial relationships rest on changes in the demand for manpower [8, p. 115] growth and fall in the shortage of current operations in some of the European and Baltic countries [9, p. 153]. They also use it to analyze the International Monetary Fund's forecasts and Fiscal Stability Treaty of the European Union on a vast sample of countries [10, p. 5], social transfers $[11$, p. $317 ; 12$, p. $91 ; 13$, p. 119; 14], and evaluate the space of possibilities and ultimate achievements [15, p. 247].

Analysis of financial dynamics in the Shanghai Cooperation Organisation member States (SCO countries) $[16$, p. $272 ; 17$, p. $214 ; 18$, p. $197 ; 19$, p. 263; 20, p. 185] includes an evaluation of growth rates of financial and economic interdependencies, such as the liquid bank reserves to assets ratio, extensive money supply, foreign exchange rate, deflator, inflation (consumer prices), loan interest rate (private sector), national trading companies.

Analyzing the financial position of the SCO countries (India, Kazakhstan, Kyrgyzstan, China, Pakistan, Russia, Tajikistan, Uzbekistan) in terms of growth rates (GR) of financial and economic interdependencies, we use indicators in the related time series with subsequent polynomial approximation, which is best fit to describe frequently changing values for analyzing diverse combinations of unstable factors. Polynomial approximation involves the power of six that cannot have more than five peaks, being sufficient for the analyzable period of time.

\section{GR Analysis of the Liquid Bank Reserves to Assets Ratio}

We show results of polynomial approximation of growth rates of the liquid bank reserves to assets ratio in the descending order of their absolute peak values (Fig. 1):

$$
\begin{aligned}
& \text { - Kazakhstan: } y=0.0479 x^{6}-1.4179 x^{5}+ \\
& +14.844 x^{4}-61.763 x^{3}+57.02 x^{2}+161.47 x- \\
& \text { - 148.74; } R^{2}=0.8555 ; \text { average } G R_{2006-2016}=26.03 \\
& \text { - Pakistan: } y=-0.0302 x^{6}+1.1056 x^{5}- \\
& -15.614 x^{4}+106.43 x^{3}-357.18 x^{2}+531.74 x- \\
& -248.8 ; R^{2}=0.7286 ; \text { average } G R_{2006-2016}=1.68 \\
& \text { - Tajikistan: } y=0.029 x^{6}-0.9856 x^{5}+ \\
& +12.781 x^{4}-80.542 x^{3}+263.22 x^{2}-441.88 x+ \\
& +313.88 ; R^{2}=0.8359 ; \text { average } G R_{2006-2016}=9.5 \\
& \text { - Russia: } y=0.0208 x^{6}-0.7586 x^{5}+10.713 x^{4}- \\
& -73.996 x^{3}+258.46 x^{2}-421.15 x+233.33 \\
& R^{2}=0.4743 ; \text { average } G R_{2006-2016}= \\
& -4.09 ; \\
& \text { - Kyrgyzstan: } y=-0.0138 x 6+0.4692 x 5- \\
& -5.8065 x^{4}+30.431 x^{3}-50.104 x^{2}-65.488 x+ \\
& +164.36 ; R^{2}=0.8509 ; \text { average } G R_{2006-2016}=8.48
\end{aligned}
$$

These results reveal that Kazakhstan leads in terms of instability of its liquid bank reserves to assets ratio with positive GR. Kyrgyzstan outperforms the other SCO countries in terms of peak values, but has worse $G R$ than Tajikistan and Kazakhstan.

\section{GR Analysis of Extensive Money Supply}

We show results of polynomial approximation of growth rates of extensive money supply in the descending order of their absolute peak values (Fig. 2):

$$
\begin{aligned}
& \text { - Tajikistan: } y=-0.7518 x^{6}+25.756 x^{5}- \\
& -337.7 x^{4}+2,130.9 x^{3}-6,685.1 x^{2}+9,583.7 x- \\
& -4,628.1 ; R^{2}=0.5464 ; \text { average } G R_{2006-2016}=-176.83 \\
& \text { - Kyrgyzstan: } y=-0.0742 x^{6}+3.354 x^{5}- \\
& -57.432 x^{4}+472.02 x^{3}-1,918.3 x^{2}+3,488.7 x- \\
& -1,970.6 ; R^{2}=0.7014 ; \text { average } G R_{2006-2016}=73.76 \\
& \text { - Pakistan: } y=0.0724 x^{6}-2.3681 x^{5}+ \\
& +29.709 x^{4}-180.5 x^{3}+552.5 x^{2}-796.03 x+ \\
& +411.75 ; R^{2}=0.6339 ; \text { average } G R_{2006-2016}=18.99
\end{aligned}
$$


- Kazakhstan: $y=-0.035 x^{6}+1.6248 x^{5}-$

$-28.678 x^{4}+244.88 x^{3}-1,047 x^{2}+2,031.9 x-$

$-1,247.2 ; R^{2}=0.7665$; average $G R_{2006-2016}=24.8$;

- Russia: $y=-0.0234 \times 6+0.9843 \times 5-16.161 \times 4+$ $+130.72 \times 3-539.95 \times 2+1,054.3 x-734.93$;

$R 2=0.6642$; average $G R_{2006-2016}=-9.1$;

- India: $y=0.0031 x^{6}-0.0928 x^{5}+0.9781 x^{4}-$ - 3.7499 $x^{3}-2.7833 x^{2}+47.386 x-76.292 ; R^{2}=0.5036$; average $G R_{2006-2016}=-4.61$;

- China: $y=0.002 x^{6}-0.0697 x^{5}+0.8341 x^{4}-$ $-3.6193 x^{3}-0.1221 x^{2}+27.014 x-21.596 ; R^{2}=0.0727 ;$ average $G R_{2006-2016}=-0.31$.

Tajikistan is seen to have the most unstable extensive money supply and very high negative $G R$ in comparison with the other SCO countries. China has more preferable peak values but its $G R$ follows those of Kazakhstan, Pakistan and Kyrgyzstan.

\section{GR Analysis of Foreign Exchange Rate}

We show results of polynomial approximation of growth rates of foreign exchange rate in the descending order of their absolute peak values (Fig. 3):

- India: $y=0.0092 x^{6}-0.3292 x^{5}+4.5981 x^{4}-$ $-31.354 x^{3}+106.99 x^{2}-165.72 x+91.51 ; R^{2}=0.4649$; average $G R_{2006-2016}=4.11$;

- Kazakhstan: $y=0.0088 x^{6}-0.3064 x^{5}+$ $+4.0959 x^{4}-26.917 x^{3}+93.114 x^{2}-172.19 x+$

$+156.21 ; R^{2}=0.9107665$; average $G R_{2006-2016}=10.17$;

- Pakistan: $y=0.0087 x^{6}-0.3149 x^{5}+$ $+4.3771 x^{4}-29.575 x^{3}+100.13 x^{2}-154.75 x+$ + 82.868; $R^{2}=0.704$; average $\mathrm{GR}_{2006-2016}=5.43$;

- Russia: $y=-0.0057 x^{6}+0.2735 x^{5}-5.0495 x^{4}+$ $+45.099 x^{3}-199.88 x^{2}+393.27 x-222.46$;

$R^{2}=0.8087$; average $G R_{2006-2016}=9.55$;

- Tajikistan: $y=-0.0029 x^{6}+0.1297 x^{5}-$

$-2.1956 x^{4}+17.604 x^{3}-67.081 x^{2}+102.53 x-$

$-23.491 ; R^{2}=0.797 ;$ average

$G R_{2006-2016}=9.14$;

- Kyrgyzstan: $y=0.0027 x^{6}-0.0618 x^{5}+0.269 x^{4}+$ $+2.9284 x^{3}-28.44 x^{2}+73.279 x-39.38 ; R^{2}=0.8698$; average $G R_{2006-2016}=5.27$;

- China: $y=0,0003 x^{6}-0,0061 x^{5}+0,0482 x^{4}-$ $-0,2338 x^{3}+1,6334 x^{2}-8,6081 x+13,745 ; R^{2}=0,8278$; average $G R_{2006-2016}=-1.82$.
India demonstrates the most unstable foreign exchange rate and positive $G R$. China has not only the most preferable peak values among the other SCO countries but also negative $G R$.

\section{GR Analysis of the Deflator Index}

We show results of polynomial approximation of growth rates of the deflator index in the descending order of their absolute peak values (Fig. 4):

Russia: $y=-0.0081 x^{6}+0.2914 x^{5}-4.0412 x^{4}+$
$+27.152 x^{3}-90.883 x^{2}+140.57 x-69.646$
$R^{2}=0.5128 ;$ average $G R_{2006-2016}=10.96$

- Kyrgyzstan: $y=-0.0055 x^{6}+0.1904 x^{5}-$ $-2.527 x^{4}+16.187 x^{3}-51.425 x^{2}+76.208 x-$ - 36.391; $R^{2}=0.4828$; average $G R_{2006-2016}=9.93$;

- China: $y=-0.0034 x^{6}+0.1158 x^{5}-1.5181 x^{4}+$ $+9.4915 x^{3}-28.796 x^{2}+39.069 x-17.281$; $\mathrm{R}^{2}=0.6496$; average $G R_{2006-2016}=3.75$;

- Pakistan: $y=0.0029 x^{6}-0.0868 x^{5}+$ $+0.9656 x^{4}-4.8818 x^{3}+11.067 x^{2}-6.9834 x+$ $+0.4065 ; R^{2}=0.7788$; average $G R_{2006-2016}=10.52$;

- Uzbekistan: $y=0.0018 x^{6}-0.0697 x^{5}+$ $+1.0218 x^{4}-7.231 x^{3}+25.264 x^{2}-37.768 x+$

$+26.559 ; R^{2}=0.9068$; average $G R_{2006-2016}=16,36$;

- Tajikistan: $y=-0.0014 \times 6+0.0336 \times 5-$ $-0.2153 x 4-0.4482 x 3+9.0458 \times 2-26.267 x+$

$+23.084 ; R 2=0.9237$; average $G R_{2006-2016}=12.87$;

- Kazakhstan: $y=-0.0011 x^{6}+0.0338 x^{5}-$ $-0.3395 x^{4}+0.8119 x^{3}+5.556 x^{2}-27.858 x+$ $+35.058 ; R^{2}=0.5478$; average $G R_{2006-2016}=12.57$;

- India: $y=0.0002 x^{6}-0.01 x^{5}+0.1993 x^{4}-$ $-1.9717 x^{3}+9.7215 x^{2}-20.206 x+15.939$; $R^{2}=0.8866$; average $G R_{2006-2016}=6.09$.

Russia demonstrates the most unstable deflator index and moderate GR (it is higher in Tajikistan, Uzbekistan and Kazakhstan). India has more preferable peak values but its $G R$ lags behind that of China.

\section{GR Analysis of Inflation (Consumer Prices)}

We show results of polynomial approximation of growth rates of inflation (consumer prices) in the descending order of their absolute peak values (Fig. 5): 


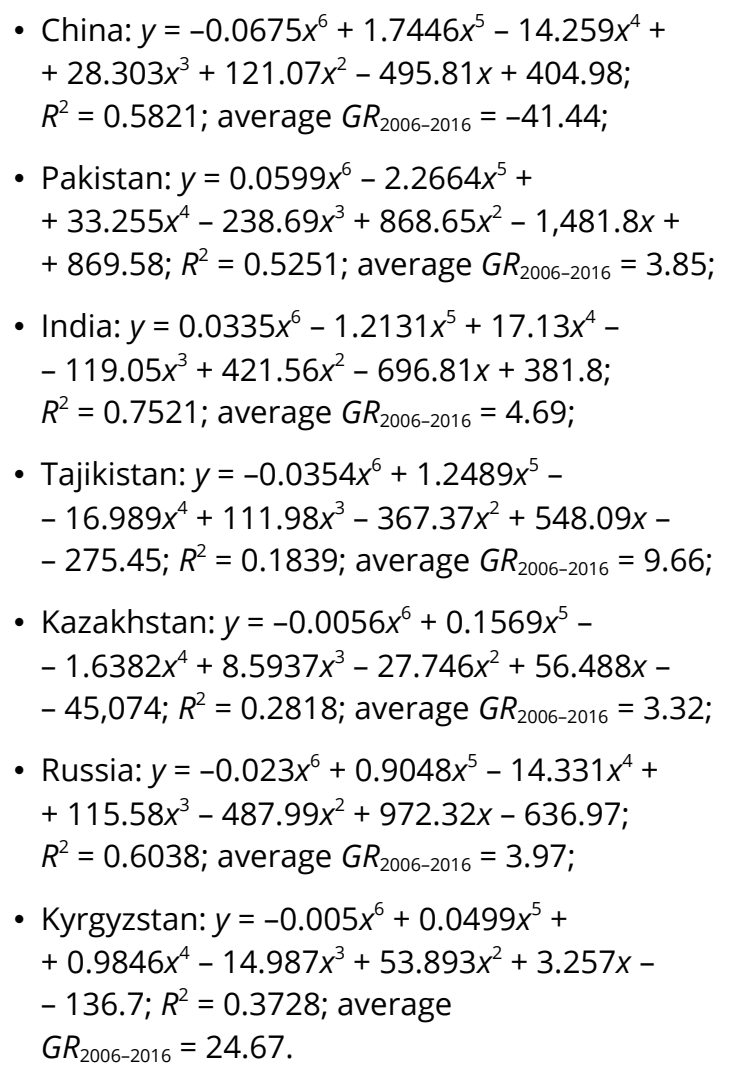

China demonstrates a more unstable inflation (consumer prices) and high negative GR. Kyrgyzstan has attractive peak values but its $G R$ significantly lags behind the other SCO countries.

\section{GR Analysis of Loan Interest Rate (Private Sector)}

We show results of polynomial approximation of growth rates of loan interest rates (private sector) in the descending order of their absolute peak values (Fig. 6):

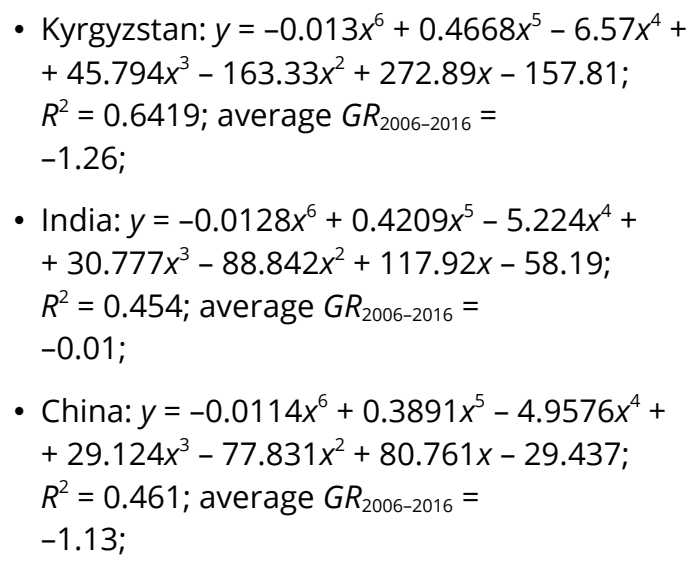

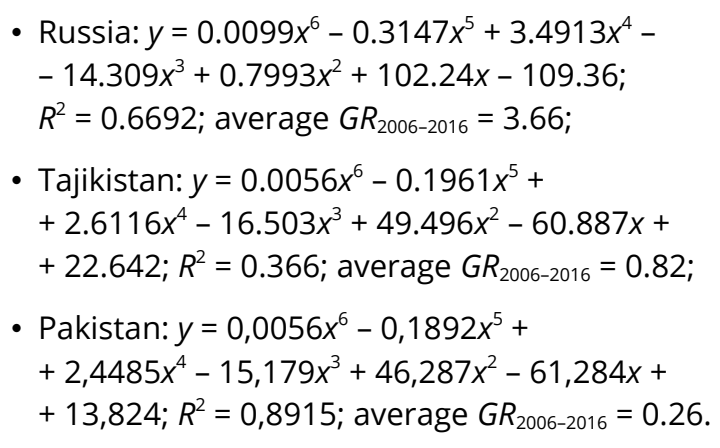

Kyrgyzstan demonstrates more unstable loan interest rates (private sector) and negative GR. Pakistan has more preferable peak values but its $G R$ lags behind those of Kyrgyzstan, India and China.

\section{GR Analysis of National Trading Companies}

We show results of polynomial approximation of growth rates of national trading companies in the descending order of their absolute peak values (Fig. 7):

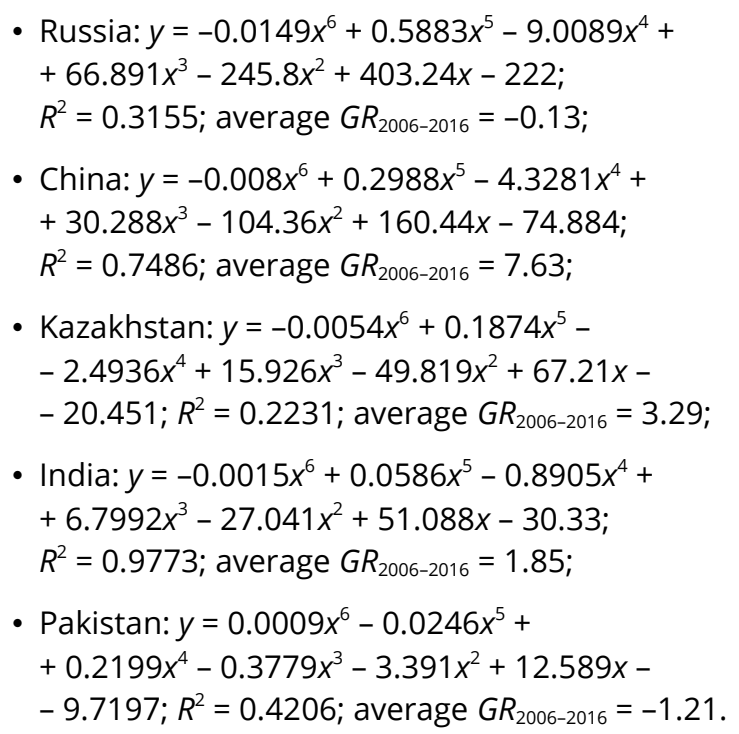

Russia's trading companies are more unstable and demonstrate negative $G R$. Pakistan has more preferable peak values but its $G R$ lags behind those of India, Kazakhstan, China and Russia.

\section{Summary Analysis of Trends in the Financial Position of the Shanghai Cooperation Organisation Member States}

Having performed the summary analysis of growth rates of the liquid bank reserves to assets ratio, extensive money supply, foreign exchange rate, deflator index, inflation (consumer prices), national trading 
companies with subsequent polynomial approximation, we revealed the following trends in the financial position of the SCO countries (Fig. 1-7):

1) high $G R_{2006-2016:}$

- Tajikistan: the liquid bank reserves to assets ratio $G R_{2006-2016}=26.03$;

- Kyrgyzstan: extensive money supply $G R_{2006-2016}=73.76$, inflation (consumer prices) $G R_{2006-2016}=24.67$;

- Kazakhstan: foreign exchange rate $G R_{2006-2016}=10.17$;

- Uzbekistan: deflator index $G R_{2006-2016}=16.36$;

- Russia: Ioan interest rate (private sector) $G R_{2006-2016}=$ 3.66;

- China: national trading companies $G R_{2006-2016}=7.63$;

2) low $G R_{2006-2016}$ :

- Russia: the liquid bank reserves to assets ratio $G R_{2006-2016}$, extensive money supply $G R_{2006-2016}=-9.1$;

- China: foreign exchange rate $G R_{2006-2016}=-1.82$, deflator index $G R_{2006-2016}=3.75$, inflation (consumer prices) $G R_{2006-2016}=-41.44$

- Kyrgyzstan: loan interest rate (private sector) $G R_{2006-2016}$ $=-1.26$;

- Pakistan: national trading companies $G R_{2006-2016}=$ -1.21 ;

3) high absolute peak values of instability:

- Kazakhstan: the liquid bank reserves to assets ratio: $y=0.0479 x^{6}-1.4179 x^{5}+14.844 x^{4}-61.763 x^{3}+57.02 x^{2}$ $+161.47 x-148.74 ; R^{2}=0.8555 ;$

- Tajikistan: extensive money supply: $y=-0.7518 x^{6}+$ $+25.756 x^{5}-337.7 x^{4}+2,130.9 x^{3}-6,685.1 x^{2}+9,583.7 x-$ $-4,628.1 ; R^{2}=0.5464 ;$

- India: foreign exchange rate: $y=0.0092 x^{6}-$ $-0.3292 x^{5}+4.5981 x^{4}-31.354 x^{3}+106.99 x^{2}-$ $-165.72 x+91.51 ; R^{2}=0.4649$;

- Russia: deflator index: $y=-0.0081 x^{6}+$ $+0.2914 x^{5}-4.0412 x^{4}+27.152 x^{3}-90.883 x^{2}+$ $+140.57 x-69.646 ; R^{2}=0.5128$; national trading companies $y=-0.0149 x^{6}+0.5883 x^{5}-9.0089 x^{4}+$ $+66.891 x^{3}-245.8 x^{2}+403.24 x-222 ; R^{2}=0.3155$;

- China: inflation (consumer prices): $y=-0.0675 x^{6}+$ $1.7446 x^{5}-14.259 x^{4}+28.303 x^{3}+121.07 x^{2}-495.81 x+$ 404.98; $R^{2}=0.5821$;
- Kyrgyzstan: loan interest rate (private sector): $y=-0.013 x^{6}+0.4668 x^{5}-6.57 x^{4}+45.794 x^{3}-163.33 x^{2}+$ $+272.89 x-157.81 ; R^{2}=0.6419 ;$

4) Iow absolute peak values of instability:

- Kyrgyzstan: the liquid bank reserves to assets ratio: $y=-0.0138 x^{6}+0.4692 x^{5}-5.8065 x^{4}+30.431 x^{3}-$ $50.104 x^{2}-65.488 x+164.36 ; R^{2}=0.8509 ;$ inflation (consumer prices) $y=-0.005 x^{6}+$ $+0.0499 x^{5}+0.9846 x^{4}-14.987 x^{3}+53.893 x^{2}+$ $+3.257 x-136.7 ; R^{2}=0.3728$;

- China: extensive money supply: $y=0.002 x^{6}-0.0697 x^{5}+0.8341 x^{4}-3.6193 x^{3}-$ $-0.1221 x^{2}+27.014 x-21.596 ; R^{2}=0.0727$; foreign exchange rate: $y=0.0003 x^{6}-0.0061 x^{5}+$ $+0.0482 x^{4}-0.2338 x^{3}+1.6334 x^{2}-8.6081 x+$ $+13.745 ; R^{2}=0.8278$;

- India: deflator index: $y=0.0002 x^{6}$ $-0.01 x^{5}+0.1993 x^{4}-1.9717 x^{3}+9.7215 x^{2}-$ $-20.206 x+15.939 ; R^{2}=0.8866$; average $G R_{2006-2016}=$ =6.09;

- Pakistan: loan interest rates (private sector): $y=0.0056 x^{6}-0.1892 x^{5}+2.4485 x^{4}-15.179 x^{3}+$ $46.287 x^{2}-61.284 x+13.824 ; R^{2}=0.8915$; national trading companies: $y=0.0009 x^{6}-0.0246 x^{5}+0.2199 x^{4}$ $-0.3779 x^{3}-3.391 x^{2}+12.589 x-9.7197 ; R^{2}=0.4206$.

\section{Conclusions}

Having analyzed trends in the financial position of the SCO countries and used polynomial approximation of $G R$ of a set of financial and economic interdependencies, we found high $G R_{2006-2016}$ in Tajikistan (the liquid bank reserves to assets ratio), Kyrgyzstan (extensive money supply, inflation (consumer prices)), Kazakhstan (foreign exchange rate), Uzbekistan (deflator index), Russia (loan interest rate (private sector)), China (national trading companies) and high absolute peak values of instability in Kazakhstan (the liquid bank reserves to assets ratio), Tajikistan (extensive money supply), India (foreign exchange rate), Russia (deflator index, national trading companies), China (inflation (consumer prices)), Kyrgyzstan (loan interest rate (private sector)).

Having focused on the financial position of the SCO countries and evaluated GR with subsequent polynomial approximation, we recorded high $G R_{2006-2016}$ in Kyrgyzstan, and low $G R_{2006-2016}$ in China, Russia. High instability is also captured in Russia, with a lower level being in China, Kyrgyzstan and Pakistan. 


\section{Figure 1}

GR of liquid bank reserves to assets ratio (2006-2016)

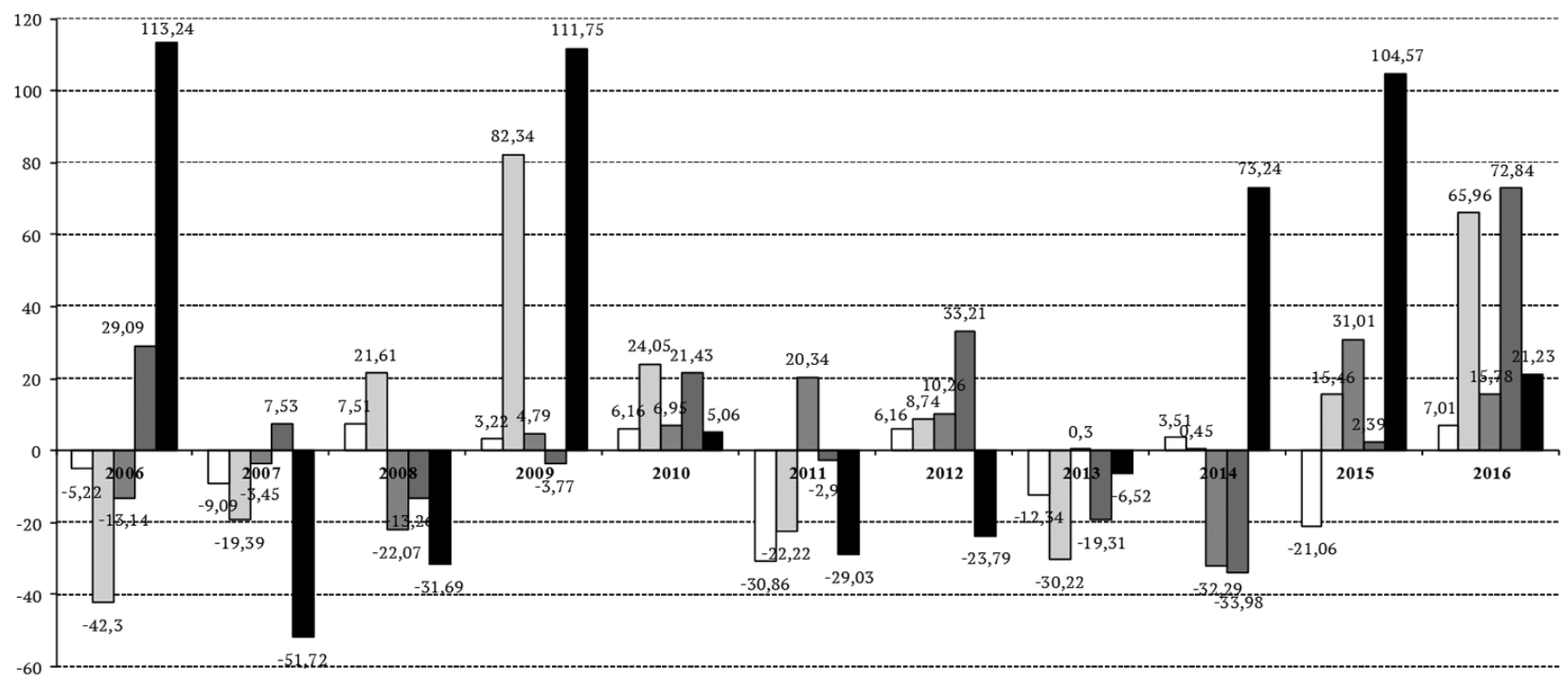

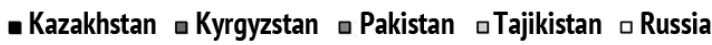

Source: Authoring based on the World Bank data.

URL: http://data.trendeconomy.ru/dataviewer/wb/wbd/wdi?kf=WDI\&time_period=

2005,2006,2007,2008,2009,2010,2011,2012,2013,2014,2015,2016\&ref_area=CHN,IND,KAZ,KGZ,PAK,RUS,TJK,UZB\&series=FD_RES_LIQU_AS_ZS

\section{Figure 2}

GR of extensive money supply (2006-2016)

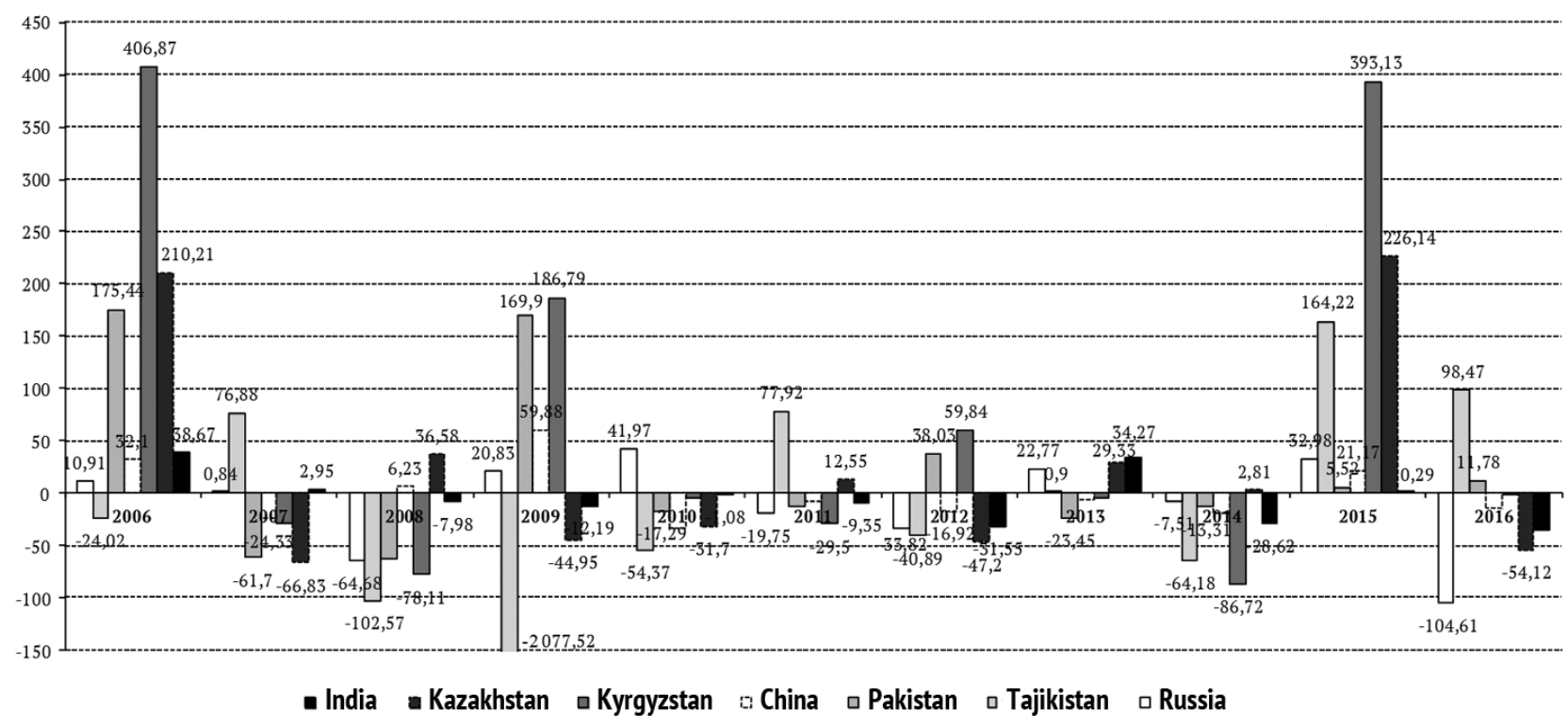

Source: Authoring, based on the World Bank data.

URL: http://data.trendeconomy.ru/dataviewer/wb/wbd/wdi?kf=WDI\&time_period=

2005,2006,2007,2008,2009,2010,2011,2012,2013,2014,2015,2016\&ref_area=CHN,IND,KAZ,KGZ,PAK,RUS,TJK,UZB\&series=FM_LBL_BMNY_ZG

Please cite this article as: Smirnov V.V., Mulendeeva A.V. Factor Analysis of Financial Standing of the Shanghai Cooperation Organisation Member States. Digest Finance, 2018, vol. 23, iss. 4, pp. 373-383.

https://doi.org/10.24891/df.23.4.373 
Figure 3

GR of exchange rate (2006-2016)

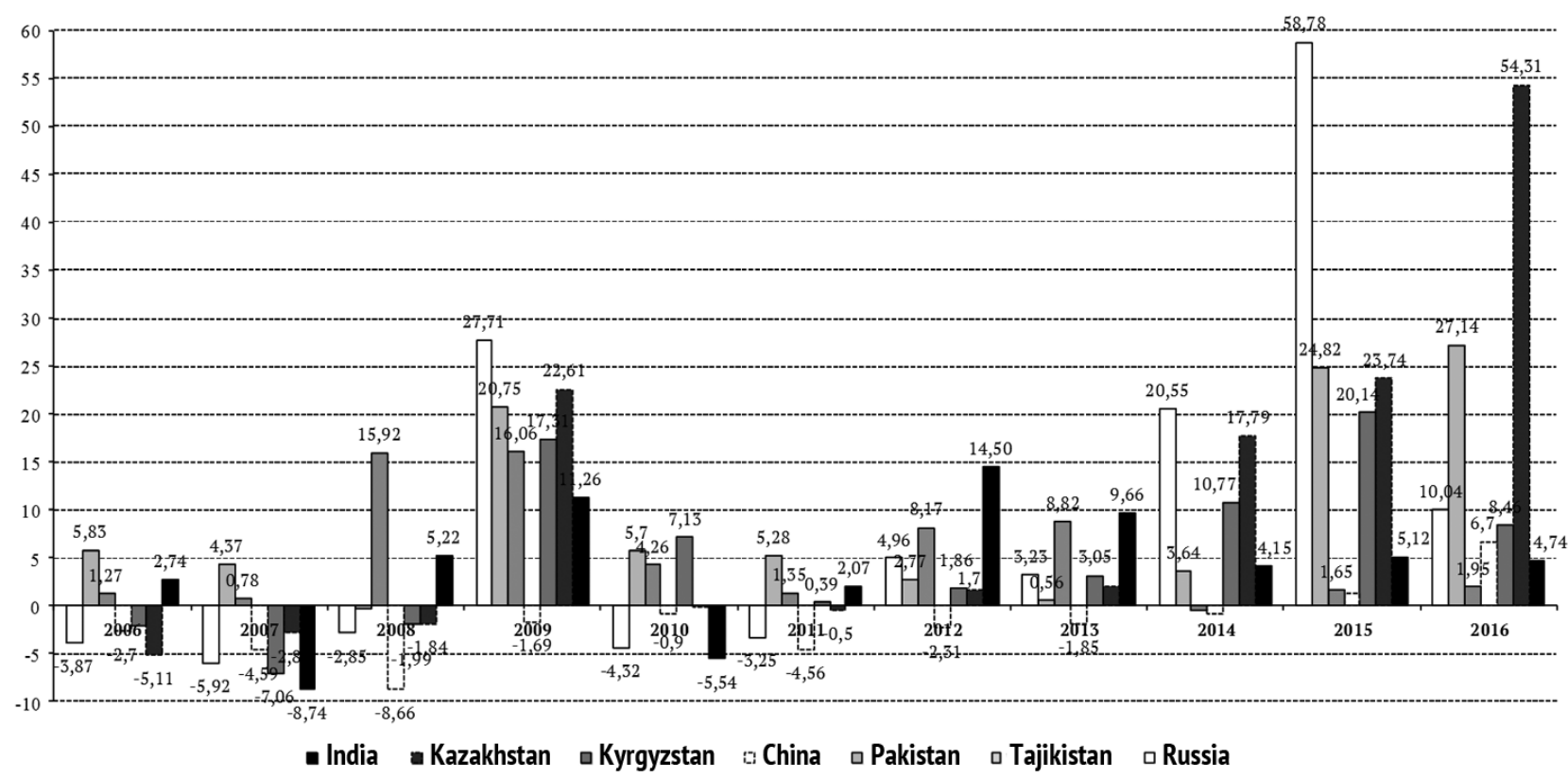

Source:Authoring based on the World Bank data.

URL: http://data.trendeconomy.ru/dataviewer/wb/wbd/wdi?kf=WDI\&time_period=

2005,2006,2007,2008,2009,2010,2011,2012,2013,2014,2015,2016\&ref_area=CHN,IND,KAZ,KGZ,PAK,RUS,TJK,UZB\&series=PA_NUS_FCRF

\section{Figure 4}

GR of deflator index (2006-2016)

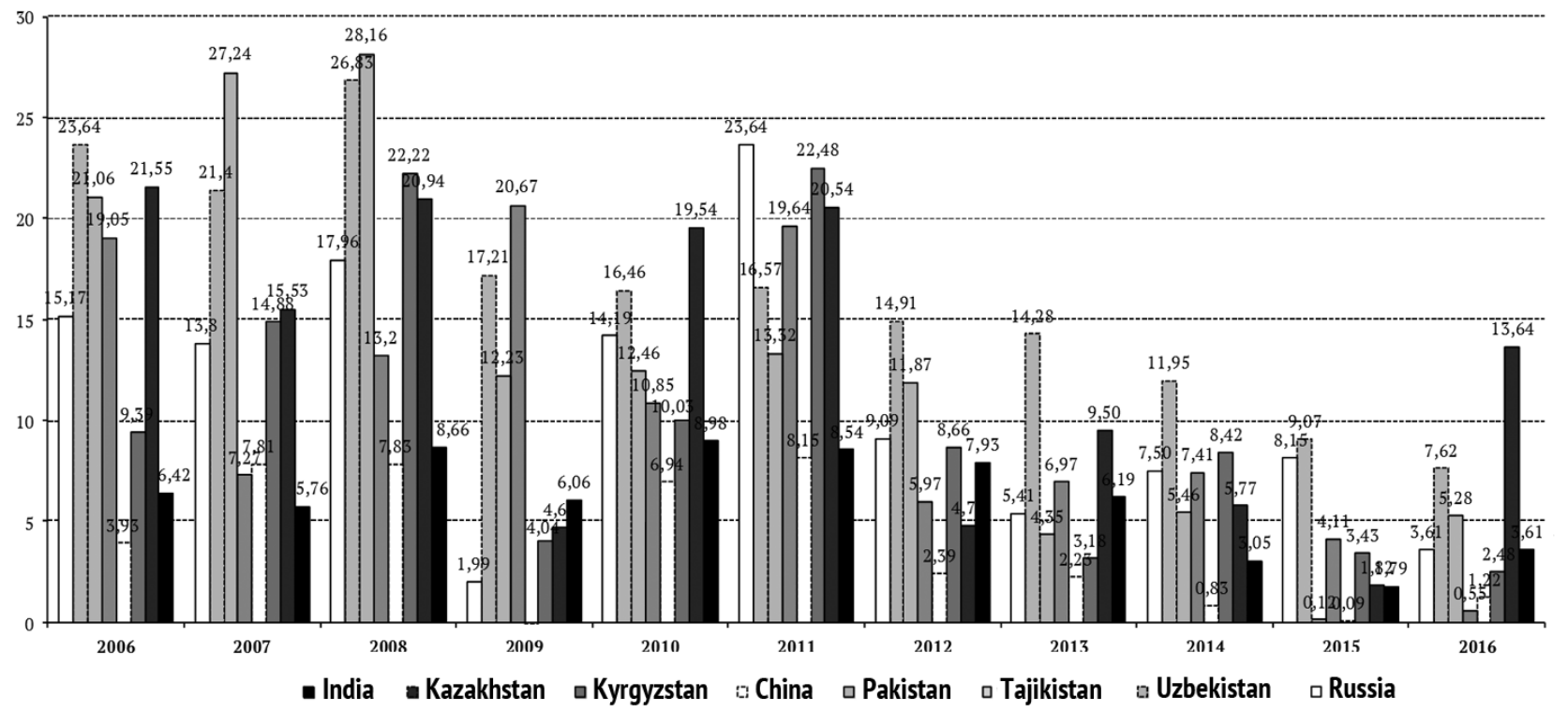

Source: Authoring based on the World Bank data.

URL: http://data.trendeconomy.ru/dataviewer/wb/wbd/wdi?kf=WDI\&time_period=

2005,2006,2007,2008,2009,2010,2011,2012,2013,2014,2015,2016\&ref_area=CHN,IND,KAZ,KGZ,PAK,RUS,TJK,UZB\&series=NY_GDP_DEFL_Z

Please cite this article as: Smirnov V.V., Mulendeeva A.V. Factor Analysis of Financial Standing of the Shanghai Cooperation Organisation Member States. Digest Finance, 2018, vol. 23, iss. 4, pp. 373-383.

https://doi.org/10.24891/df.23.4.373 
Figure 5

GR of inflation (consumer prices) (2006-2016)

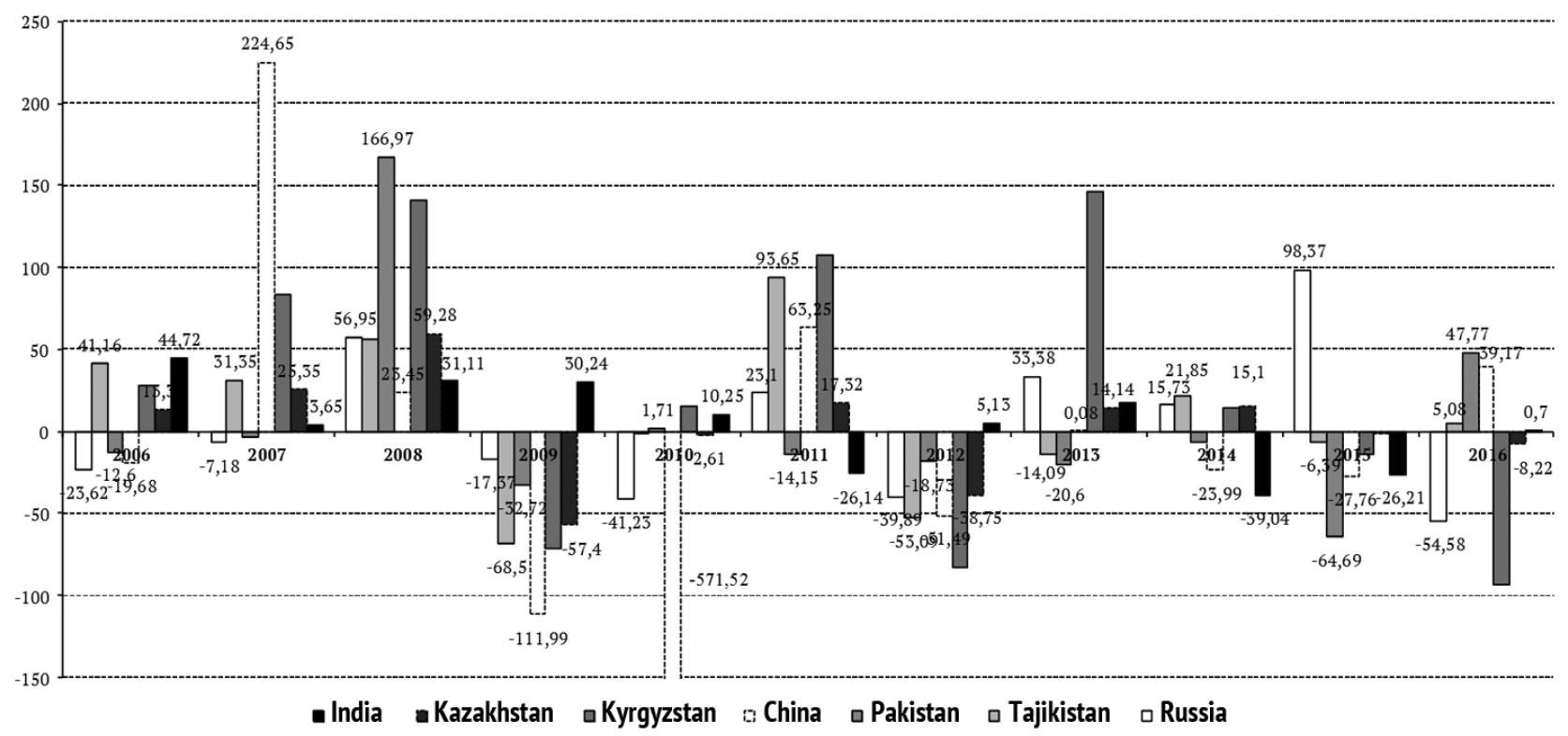

Source:Authoring based on the World Bank data.

URL: http://data.trendeconomy.ru/dataviewer/wb/wbd/wdi?kf=WDI\&time_period=

2005,2006,2007,2008,2009,2010,2011,2012,2013,2014,2015,2016\&ref_area=CHN,IND,KAZ,KGZ,PAK,RUS,TJK,UZB\&series=FP_CPI_TOTL_ZG

\section{Figure 6}

GR of interest rate on loans (private sector) (2006-2016)

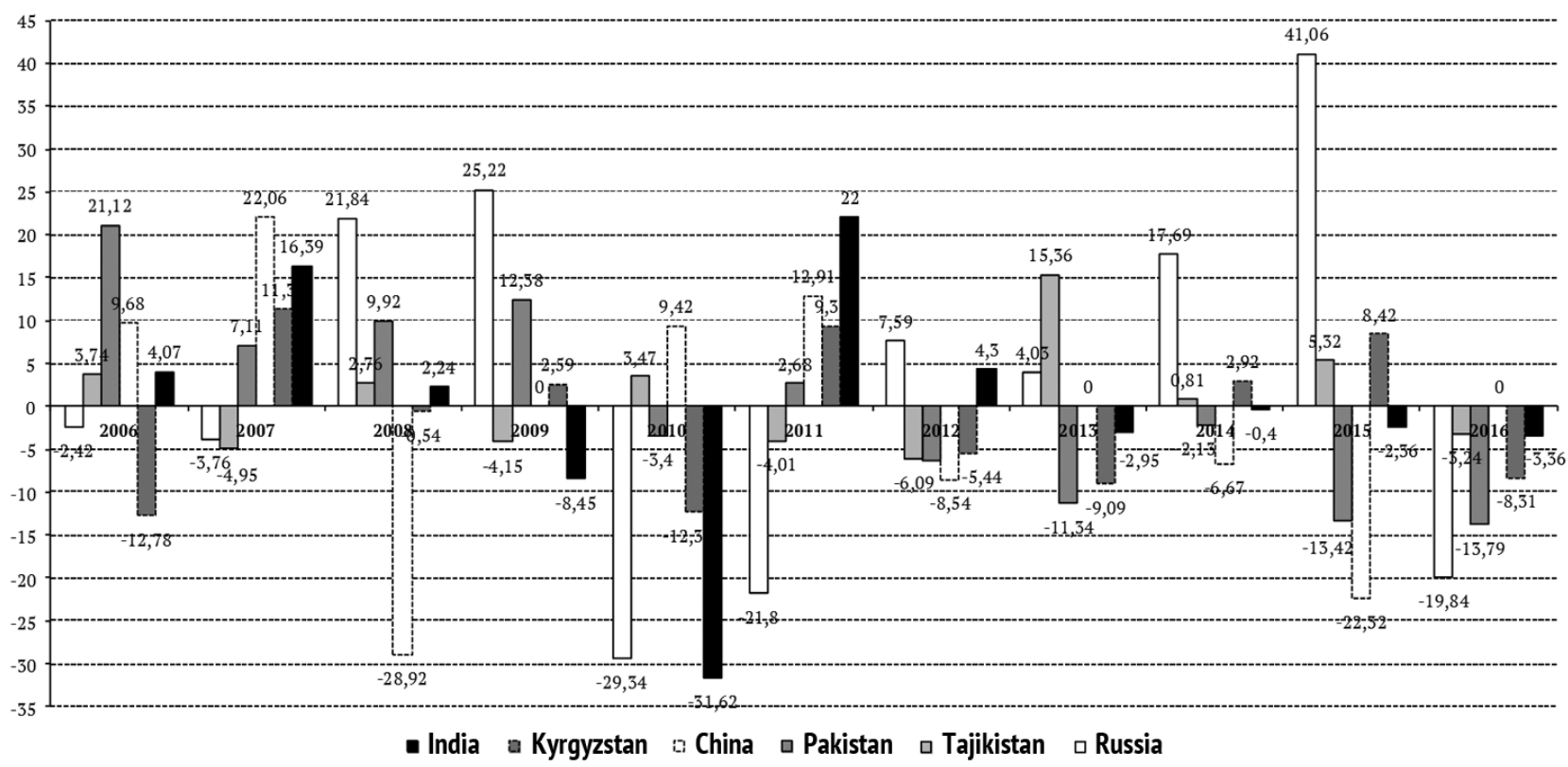

Source: Authoring based on the World Bank data.

URL: http://data.trendeconomy.ru/dataviewer/wb/wbd/wdi?kf=WDI\&time_period=

2005,2006,2007,2008,2009,2010,2011,2012,2013,2014,2015,2016\&ref_area=CHN,IND,KAZ,KGZ,PAK,RUS,TJK,UZB\&series=FR_INR_LEND

Please cite this article as: Smirnov V.V., Mulendeeva A.V. Factor Analysis of Financial Standing of the Shanghai Cooperation Organisation Member States. Digest Finance, 2018, vol. 23, iss. 4, pp. 373-383.

https://doi.org/10.24891/df.23.4.373 


\section{Figure 7}

GR of listed domestic companies (2006-2016)

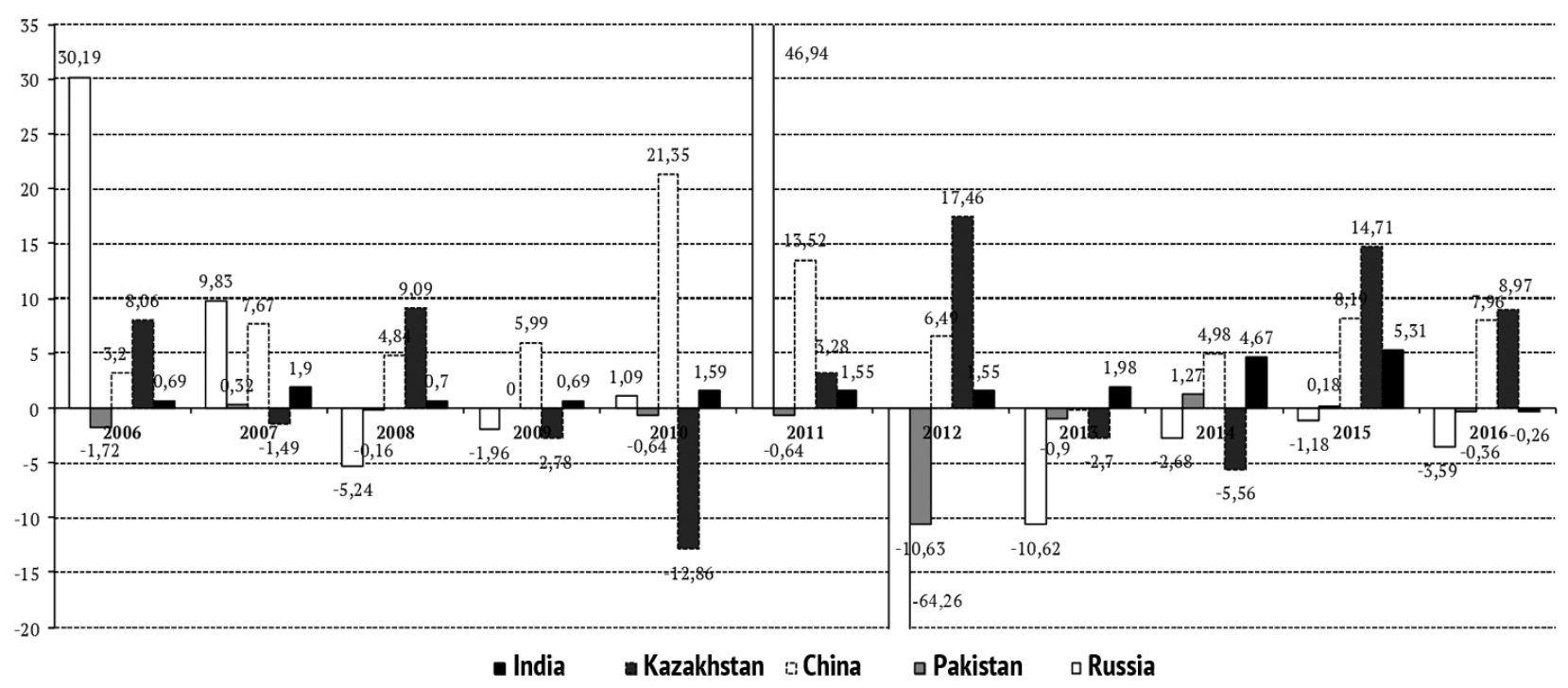

Source: Authoring based on the World Bank data.

URL: http://data.trendeconomy.ru/dataviewer/wb/wbd/wdi?kf=WDI\&time_period=

2005,2006,2007,2008,2009,2010,2011,2012,2013,2014,2015,2016\&ref_area=CHN,IND,KAZ,KGZ,PAK,RUS,TJK,UZB\&series=CM_MKT_LDOM_NO 


\section{References}

1. Lyubushin N.P., Babicheva N.E., Lylov A.I. [Economic analysis of business entities' sustainable development under cyclicality]. Ekonomicheskii analiz: teoriya i praktika = Economic Analysis: Theory and Practice, 2018, vol. 17, iss. 1, pp. 4-17. (In Russ.) URL: https://doi.org/10.24891/ea.17.1.4

2. Lyubushin N.P., Kondrat'ev R.Yu. [The modern concept and approaches in the economic analysis of the creditworthiness of borrowers]. Finansovaya analitika: problemy i resheniya = Financial Analytics: Science and Experience, 2017, vol. 10, iss. 12, pp. 1324-1345. (In Russ.) URL: https://doi.org/10.24891/fa.10.12.1324

3. Mitsek S.A., Mitsek E.B. [Economic growth, inflation, investments and incomes in the Russian Federation: Econometric model-based analysis and forecast]. Ekonomicheskii analiz: teoriya i praktika = Economic Analysis: Theory and Practice, 2018, vol. 17, iss. 1, pp. 18-29. (In Russ.) URL: https://doi.org/10.24891/ea.17.1.18

4. Efimova O.V. [Integrating the aspects of sustainable development into the investment decision validation process]. Ekonomicheskii analiz: teoriya i praktika = Economic Analysis: Theory and Practice, 2018, vol. 17, iss. 1, pp. 48-65. (In Russ.) URL: https://doi.org/10.24891/ea.17.1.48

5. Oborin M.S., Sheresheva M.Yu., Shimuk O.V. [Development of a system of indicators of assessment, analysis and monitoring of the resource potential of the region]. Finansy $i$ kredit = Finance and Credit, 2018, vol. 24, iss. 1, pp. 154-177. (In Russ.) URL: https://doi.org/10.24891/fc.24.1.154

6. Leonov A.V., Pronin A.Yu. [The methodology for managing high-tech production during the formation of Science and Technology knowledge resources]. Natsional'nye interesy: prioritety $i$ bezopasnost' = National Interests: Priorities and Security, 2018, vol. 14, iss. 2, pp. 200-220. (In Russ.) URL: https://doi.org/10.24891/ni.14.2.200

7. Egger P., Wamser G. Multiple Faces of Preferential Market Access: Their Causes and Consequences. Economic Policy, 2013, vol. 28, iss. 73, pp. 143-187. URL: https://doi.org/10.1111/1468-0327.12003

8. Overman H.G., Puga D. Unemployment Clusters Across Europe's Regions and Countries. Economic Policy, 2002, vol. 17, iss. 34, pp. 115-148. URL: https://doi.org/10.1111/1468-0327.00085

9. Joong Shik Kang, Shambaugh J.C. The Rise and Fall of European Current Account Deficits. Economic Policy, 2016, vol. 31, iss. 85, pp. 153-199. URL: https://doi.org/10.1093/epolic/eiv018

10. Eichengreen B., Panizza U. A Surplus of Ambition: Can Europe Rely on Large Primary Surpluses to Solve Its Debt Problem? Economic Policy, 2016, vol. 31, iss. 85, pp. 5-49. URL: https://doi.org/10.1093/epolic/eiv016

11. Stifel D., Christiaensen L. Tracking Poverty Over Time in the Absence of Comparable Consumption Data. The World Bank Economic Review, 2007, vol. 21, iss. 2, pp. 317-341. URL: https://doi.org/10.1093/wber/lhm010

12. Duclos J.-Y., Sahn D., Younger S.D. Robust Multidimensional Spatial Poverty Comparisons in Ghana, Madagascar, and Uganda. The World Bank Economic Review, 2006, vol. 20, iss. 1, pp. 91-113. URL: https://doi.org/10.1093/wber/lhj005

13. Budina N., Van Wijnbergen S. Quantitative Approaches to Fiscal Sustainability Analysis: A Case Study of Turkey since the Crisis of 2001. The World Bank Economic Review, 2009, vol. 23, iss. 1, pp. 119-140. URL: https://doi.org/10.1093/wber/lhn011

14. Karlan D., Thuysbaert B. Targeting Ultra-poor Households in Honduras and Peru. The World Bank Economic Review, 2016, Ihw036. URL: https://doi.org/10.1093/wber/lhw036

15. Peragine V., Palmisano F., Brunori P. Economic Growth and Equality of Opportunity. The World Bank Economic Review, 2014, vol. 28, iss. 2, pp. 247-281. URL: https://doi.org/10.1093/wber/lht030

16. Yoder B.K. Regional Relations and the Future of China's Foreign Policy. International Studies Review, 2014 , vol. 16, iss. 4, pp. 702-704. URL: https://doi.org/10.1111/misr.12177 
17. Tessman B., Wolfe W. Great Powers and Strategic Hedging: The Case of Chinese Energy Security Strategy. International Studies Review, 2011, vol. 13, iss. 2, pp. 214-240.

URL: https://doi.org/10.1111/j.1468-2486.2011.01022.x

18. Kelly R.E. Security Theory in the 'New Regionalism'. International Studies Review, 2007, vol. 9, iss. 2, pp. $197-229$. URL: https://doi.org/10.1111/j.1468-2486.2007.00671.x

19. Faruqee R., Coleman J.R., Scott T. Managing Price Risk in the Pakistan Wheat Market. The World Bank Economic Review, 1997, vol. 11, iss. 2, pp. 263-292. URL: https://doi.org/10.1093/wber/11.2.263

20. Rama M., Scott K. Labor Earnings in One-Company Towns: Theory and Evidence from Kazakhstan. The World Bank Economic Review, 1999, vol. 13, iss. 1, pp. 185-209. URL: https://doi.org/10.1093/wber/13.1.185

\section{Conflict-of-interest notification}

We, the authors of this article, bindingly and explicitly declare of the partial and total lack of actual or potential conflict of interest with any other third party whatsoever, which may arise as a result of the publication of this article. This statement relates to the study, data collection and interpretation, writing and preparation of the article, and the decision to submit the manuscript for publication. 